\title{
Coordinated International Economic Expansion: Are Convoys or Locomotives the Answer?
}

\author{
GEOFFREY E. WOOD and NANCY AMMON JIANAKOPLOS
}

American diplomats have been pressuring the other "locomotive" countries - West Germany and Japan — to take steps to rem flate their economies. This would have the effect of creating more consumer demand and therefore more world trade. Such an "export" of the American recovery would also, incidentally, serve to bring down unemployment in the United States. ${ }^{1}$

The "locomotive" approach to current international economic policy recommends that the three major industrial trading countries of the world boost demand within their countries so that demand for the output of other nations would also expand. It is believed that this expansion would trigger an exportled expansion in the "non-locomotive" countries." A modification of the locomotive approach, the "convoy" approach, has recently become a popular alternative proposal. ${ }^{3}$ This policy prescription calls for coordinated expansion

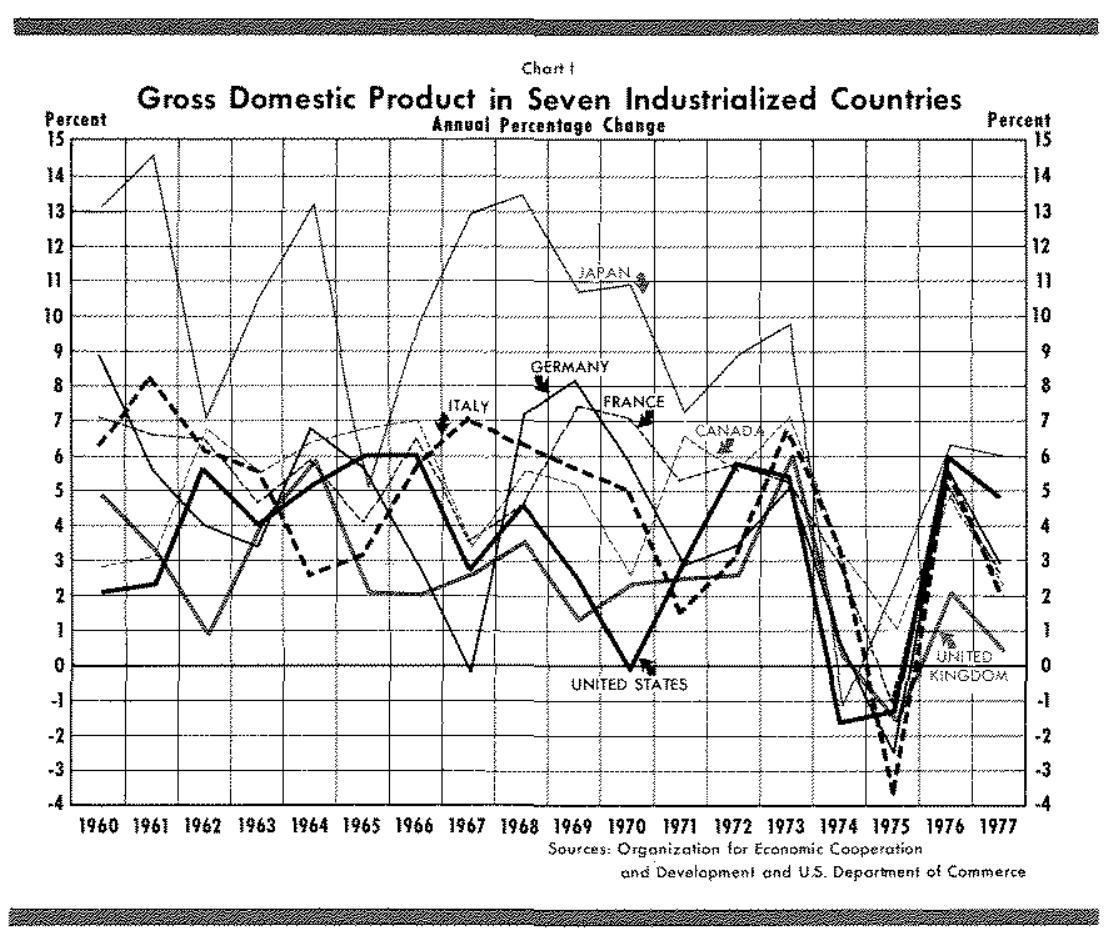
by most countries, not just the "locomotives."

\section{TIIE SETTING}

Movements in output in the major Western economies were more closely correlated in the 1970 s than

TRobert D. Hershey, Jr." "The Marked-Down Dollar," New York Times, March 19, 1978.

2This recommendation has been advanced by, among others, the Organization for Economic Cooperation and Development, Economic Outlook (July 1976, December 1976, July 1977); the Council of Economic Advisers, Economic Report of the President (Washington, D.C.: United States Government Printing Offee, 1978); and Paul McCracken et al., Towards Full Employment and Price Stability (Paris: Organization for Economic Cooperation and Development, 1977).

"See Economic Outlook (December 1977) and Philip Revzin "OECD Economic Growth Seen Trailing Prior Estimates if Measures Aren't Taken," The Wall Street Journal, May 30, 1978 . in the $1960 \mathrm{~s}$ (Chart $\mathrm{I}) .^{4}$ Following a mild recession in 1970, growth of real gross domestic product (GDP) from 1971 to 1973 expanded at an average annual rate of 5.2 percent in the seven largest economies, with the lowest average growth rate, in the United Kingdom, not differing by more than 5 percentage points from that of the fastest growing country, Japan (Table I).$^{5}$ By comparison, over the period

\footnotetext{
4 more detailed description of the situation during part of this period is provided in Donald S. Kemp, "Economic Activity in Ten Major Industrial Countries: Late 1973 through Mid-1976," this Review (October 1976), pp. 8-15.

The seven largest economies of the Western industrialized nations are Canada, France, Germany, Italy, Japan, the United Kingdom, and the United States. GDP equals GNP minus thet investment income from abroad.
} 


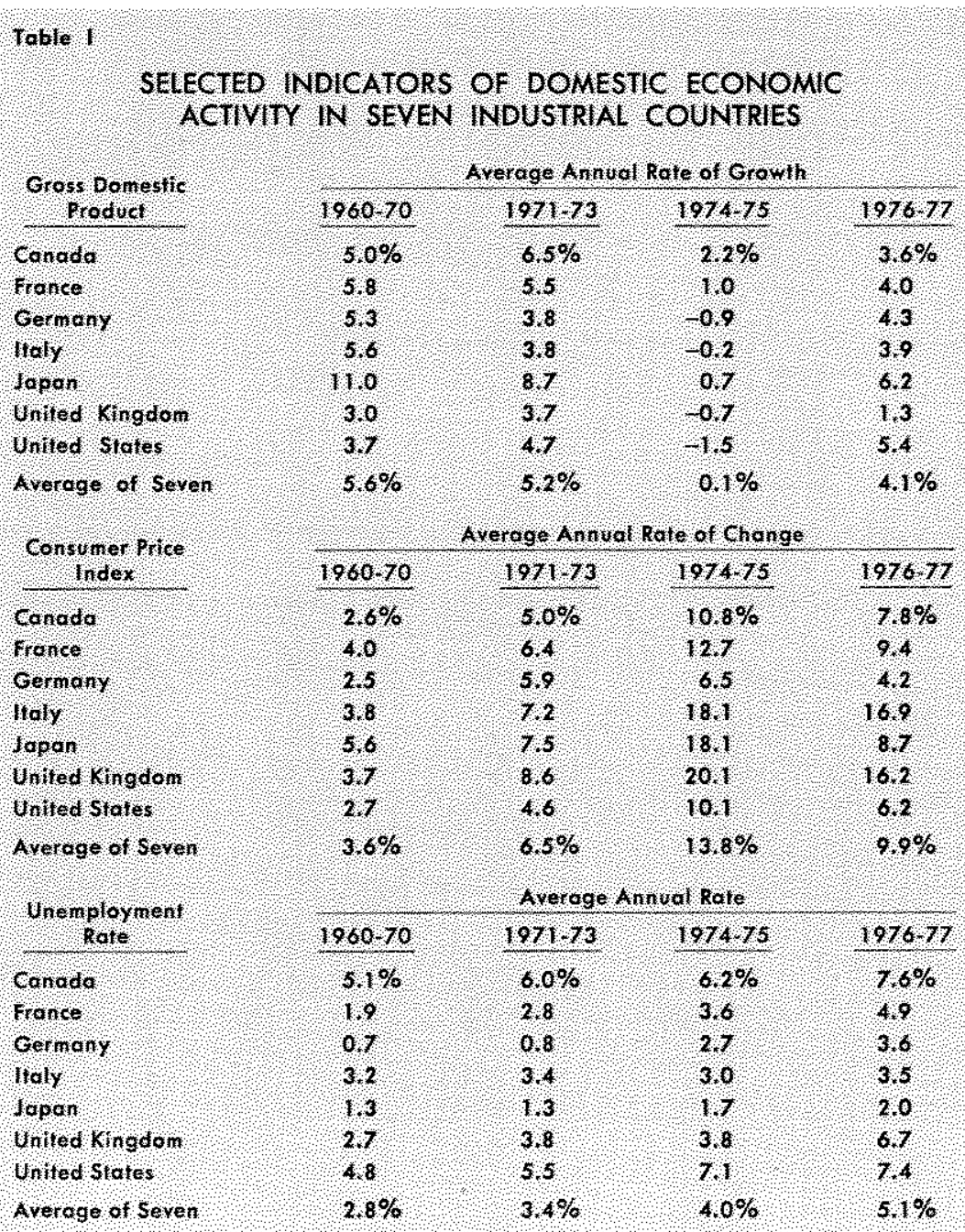

Soarce Internationat Monetary fund, Organization for Eoonomid Cooperation and Dexetopment US Departhent of Comineree, and US. Department of Laber.
Although synchronization of output growth increased in the 1970 , rates of inflation experienced across these countries have become more diverse (Chart II). From 1960 to 1970 , the average annual inflation rate differed by only 3 percentage points between the country with the highest average inflation rate and that with the lowest. However, during the 1976-77 period, these inflation rates differed by 13 percentage points. ${ }^{7}$ In addition, the inflation rate in each of the seven countries in the 1970 s has been well above the average of the $1960 \mathrm{~s}$.

The large differences in inflation rates have contributed substantially to wide fluctuations in exchange rates. There are also wide disparities in the current account balances of the countries (Table II) ${ }^{8}$ It is feared that these factors, if they persist, will lead to increased restrictions on international trade, as countries seek to adjust their current account balances through the imposition of tariffs, quotas, and other protectionist measures. Also, some analysts believe that such widely fluctuating exchange rates inhibit intemational trade and reduce the benefits of economic specialization across the world. ${ }^{10}$

In addition to high inflation rates, most countries have also experienced unemployment rates significantly above those recorded during the $1960 \mathrm{~s}$. In the from 1960 to 1970 the spread between average annual growth rates was 8 percentage points. ${ }^{6}$

During the 197475 period, following the quadrupling of oil prices by the OPEC countries, other supply shocks, such as a poor world grain harvest, and a tightening of monetary and fiscal policies, the major countries experienced severe recessions. Over this period, average real GDP growth for these seven countries came to a virtual standstill, with a spread of only 3.7 percentage points between the fastest and slowest growth rates. Since then, expansion has resumed in each economy, with the increase in real GDP averaging 4.1 percent per year in the seven countries during 1976-77.

\footnotetext{
6 A statistical test confirmed that the standard deviation in the growth rates of the seven countries was significantly less in the period 1971-77 than during 1960-70.
} view of some forecasters, this situation would be exacerbated by the sluggish growth rates of output

${ }^{7}$ A statistical test confirmed that the standard deviation in infation rates of the seven countries was significantly greater in the period 1971-77 than during 1960-70.

8The current account balance is the net export of goods and services including unilateral transfers. Unilateral transfers include private gifts to foreigners and government foreign assistance grants, but exclude military grants. See John Pippenger, "Balance-of-Payments Deficits: Measurement and Interpretation," this Retiew (November 1973), pp. 6-14.

"MeCracken, Touards Full Employment and Price Stability, p. 31 .

10For a description of how trade leads to mutually beneficial specialization, see Geoffrey $E$. Wood and Donglas $R$. Mudd, "The Recent U.S. Trade Deficit - No Cause For Panic," this Review (April 1978), pp, 2-7. Discussion and additional references on fixed versus floating exchange rates are found in Donald S. Kemp, "The U.S. Dollar in International Markets: Mid-1970 to Mid-1976," this Review (August 1976), pp. $7 \times 14$. 


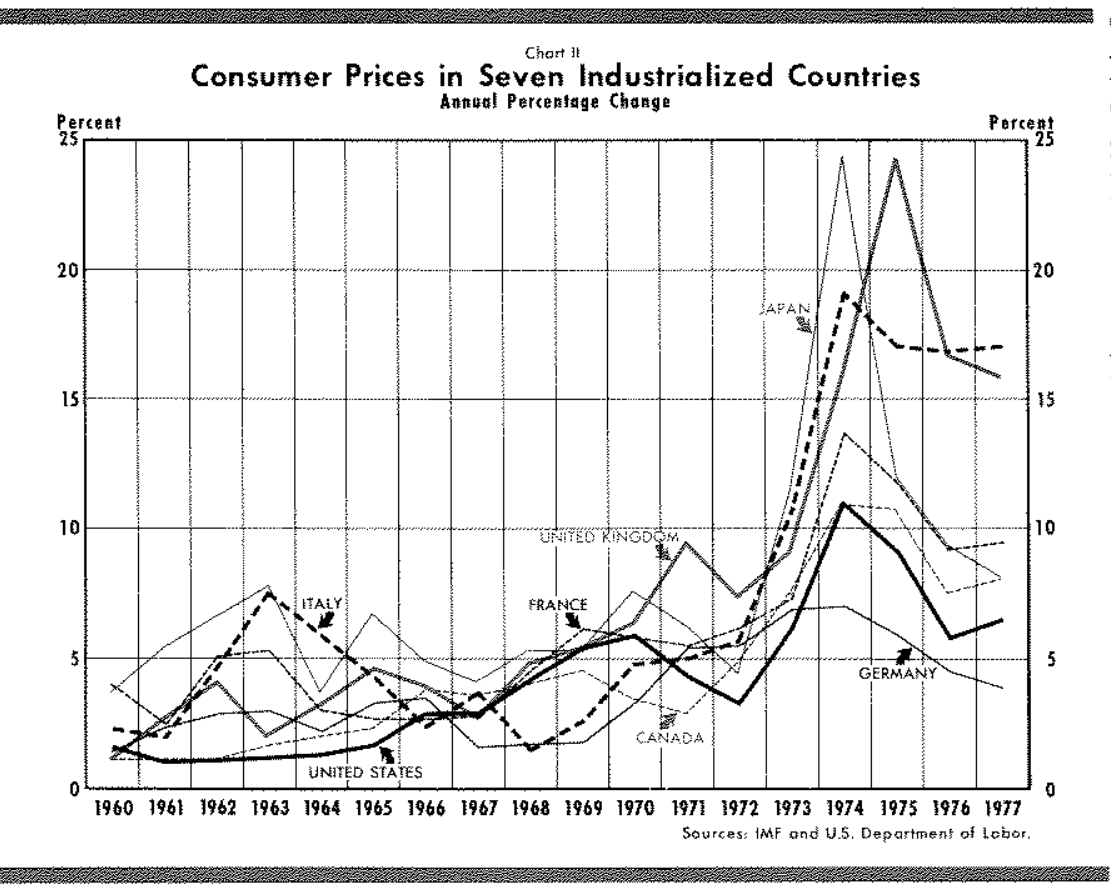

ordinated, but varying, expansion were propounded by, among others, U.S. offcials and the Secretariat of the Organization for Economic Cooperation and Development (OECD). ${ }^{12}$

\section{The Locomotive Approach}

The OECD Secretariat espoused the locomotive approach in its December 1976 Economic Outlook:

In a number of countries demand will have to continue to be kept on a tight rein until the economy is in better balance. But the handfull of countries where price behavior is being brought into line with acceptable norms and where the balance of payments is strong can afford domestic demand trends which keep their economies well up to the sort of medium-term recovery path which OECD governments jointly agreed last June. And international considerations make it highly desirable

projected for these countries. ${ }^{11}$ It has been asserted that unless growth is accelerated, further reductions in unemployment will not be achieved. At an extreme, some observers fear the world will sink into another recession.

When the locomotive approach was first proposed in 1976, Germany, Japan, and the United States were considered strong economies with current accounts in surplus or near balance and relatively low inflation rates. Countries such as Canada, France, Italy, and the United Kingdom were experiencing current account deficits and higher inflation rates.

By 1977, however, the situation had changed. Inflation in the United States, although remaining relatively low, had accelerated and the current account registered a large deficit. On the other hand, the current accounts of two "weak" countries, Italy and the United Kingdom, moved nearer to balance and inflation decelerated in the United Kingdom and France. Growth of output, however, in all the countries except Japan and the United States fell to much more sluggish rates.

\section{POLIOV PRESCRIITINS FOR TNOUSTRAITRD COUNTRTS}

Against this background of somewhat hesitant output growth, high and disparate inflation rates, and divergent current account balances, policies for co-

\footnotetext{
11See, for example, Economic Report of the President, 1978,
} pp. 112-13. that these countries, which include the three biggest economies, should ensure this. Because, unless home demand is growing faster than output in the stronger countries, world trade will not be sufficiently buoyant to enable the other economies to move into an orbit of export-led growth. 13

The locomotive approach calls for expansionary policies in the United States, Germany, and Japan, with the aim of achieving sustained growth and price stability in all the countries of the OECD. Expansionary policies are intended to encourage investment in the locomotive countries so as to sustain their expansions into the future. Policy stimulus would also provide increased demand for imports from the rest of the world, which would draw the other countries into an export-led growth. At the same time the "weaker" countries are advised to restrain domestic demand in order to bring down their inflation rates and move their current accounts towards surplus. Hence, the term "locomotive" refers to the "strong" countries pulling the "weaker" countries.

\section{The Convoy Approach}

In its December 1977 Economic Outlook, the OECD Secretariat altered its policy approach, sug-

12The OECD was established in 1960. The members of the OECD are Australia, Austria, Belgitum, Canada, Denmark, Finland, France, the Federal Republic of Germany, Greece, Iceland, Ireland, Italy, Japan, Luxembourg, the Netherlands, New Zealand, Norway, Portugal, Spain, Sweden, Switzerland, Turkey, the United Kingdom, and the United States.

${ }^{13}$ Economic Outlook (December 1976), p. 5. 


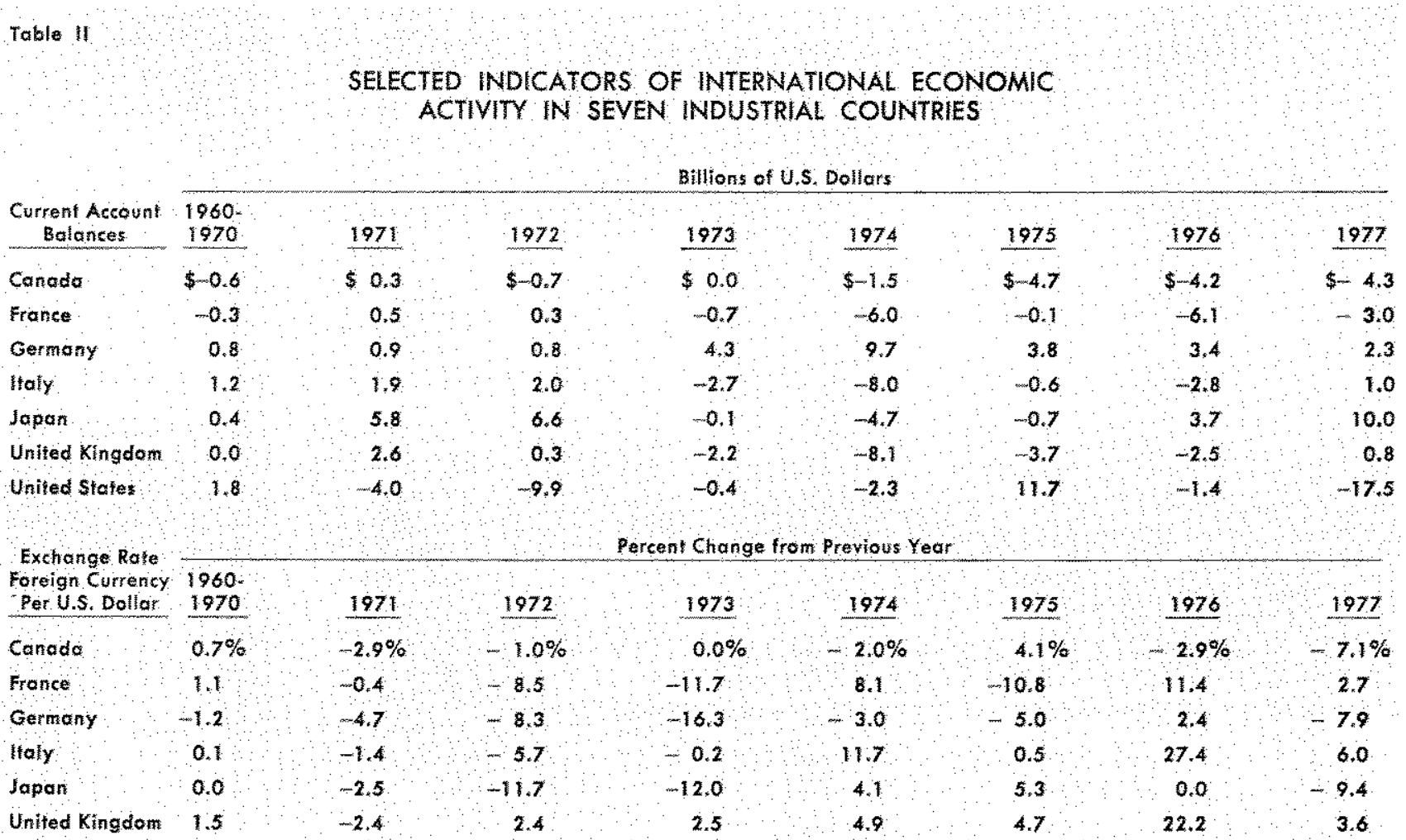

Souree Organization fof Fconomic Cooperation ard Development and International Monetary Fund.

gesting stimulative policies, but to a lesser degree and with a timing differential, for weak as well as strong countries:

It will be essential that the countries facing no or relatively small - balance-of-payments constraints should take up slack in their economies faster and somewhat earlier than most of the rest. This is not to say that these comtries, simply by expanding their own domestic demand, could be expected to pull the other countries up with them, as has sometimes been suggested. But if countries with strong payments positions ensure that their domestic demand rises faster than their GNP, others will subsequently be able to afford to impart some stimulus to their own growth rates, because their payments balances will be moving in the right direction. ${ }^{14}$

This proposal for coordinated expansionary policy is termed the "convoy" approach - there are leaders, but every unit propels its own activity. The convoy approach was proposed to take account of the impact of exchange rate changes on the expansionary policies of individual countries, ${ }^{ \pm 5}$ and has gamed favor recently. As one supporter of the convoy approach

\footnotetext{
14Economic Outlook (December 1977), p. 8.
}

1.s Ibid., p. 9. has stated "Locomotives may well pull a train but they cannot carry goods or passengers, the convoy theory seems more apt to cure the economic ills of the world."1e

\section{SOME NEGLECTED CONSIDERATIONS}

\section{Is There Spare Capacity?}

Both the locomotive and convoy approaches are expansionary policies based on the assumption that there is a large measure of unused capacity in most OECD economies. ${ }^{17}$ Faster growth is assumed to be both feasible and attainable without aggravation of intlation. The OECD Secretariat estimated that the gap between potential and actual production in 1975 was 10 percent for the OECD countries as a group..$^{18}$ Since the OECD expects potential output to increase by 4 percent per annum, it advised that actual growth of output should be expanded to 5.5 percent per

\footnotetext{
16Nicolas J. Baer, "Don't Quarrel with the Price," Euromoney (May 1978 ), p. 55 .

1 See Economic Report of the President, 1978, p. 111; Economic Outlook (December 1976), pp. 19-20, and (December 1977 ), p. 13 .

18 See Economic Outlook (June 1976), p. 132.
} 
annum to close the gap between actual and potential output by $1980^{19}$

Recent evidence suggests, however, that shocks such as the quadrupling of oil ptices since 1973 caused a permanent reduction in the level of potential output. ${ }^{20}$ The increase in the relative price of energy increased the costs of production and thereby permanently reduced the capacity of producers to supply goods and services.

While this analysis applies to all of the OECD comntries, statistical tests of the validity of these conclusions and the magnitude of the reduction in potential output have been undertaken principally for the United States. These tests indicate that potential output is now more than 4 percent below the trend existing before the oil price increases. ${ }^{21}$ While the size of the reduction may not be the same for all the OECD comntries, it is reasonable to assume that there has been a significant reduction in potential output in all of these countries. ${ }^{22}$

However, the OECD Secretariat and other proponents of these expansionary policies have not taken the loss in the productivity of existing resources into account in their formulation of stabilization policy recommendations. The expansionary locomotive and convoy approaches ignore the reduction of potential output.

\section{Why Wait for the Locomotives?}

Granting that there may be a case for expanding demand (and we grant this only for the sake of pursuing the analysis further), what grounds are there for suggesting that stimulus only come from the locomotive economies?

19 bid, p. 126.

sosee Robert I. Rasche and fohn A. Tatom, "The Effects of the New Energy Regine on Economic Capacity, Production, and Prices, this Review (May 1977), pp, 2-12, and Peter K. Clark "A New Estimate of Potential GNP" U.S. Congress, Joint Economic Committee, The 1977 Economic Report of the President, 95th Cong., 1st sess., January 19, February 2 and 3,1977 , pp. $39-55$.

"1rasche and Tatom, "The Effects of the New Energy Regime," p. 11.

${ }^{2}$ This view has also been taken by Peter Korteweg, for example, in "Overhanling the OECD Strategy for Stabilizing the International Economy" (preliminary position paper prepared for the second meeting of the Shadow European Economic Policy Committee, Brussels, Belginm, May 29-31, 1978 ), and Jacques R. Artus, "Measures of Potential Output in Manufacturing for Eight Industrial Comeries, 195578," International Monetary Ftund Staff Papers (March 1977 ), pp. $1-35$.
There may well have been times in the past when comtries in surplus on their current account could reasonably have been pressed to expand demand in order to help other countries. Such a period was the Bretton Woods era of pegged exchange rates - from the late 1940 s to the final breakdown of the system in the early 1970s.

Most countries were then reluctant to change their exchange rates, an attitude which could exert a severe constratint on domestic economic policies. Expansion of demand at home would worsen the trade balance and put the exchange rate under pressure unless the capital account improved to offset the trade deficit, ${ }^{23}$ Hence, asking comtries in trade surplus to expand demand at home could be seen as a natural consequence of the commitment not to change exchange rates. Their demand expansion would stimulate demand in other countries also.

But countries have moved to a system of floating exchange rates. It is now widely accepted that domestic economic policies will not be subordinated to keeping exchange rates firmly in place. Under present circumstances, if a country wishes to expand domestic demand, there is absolutely no international economic commitment to stop it.

There is, however, another reason for asking that demand stimulus come only from abroad. In the short run, internally-generated demand is not necessarily a perfect substitute for externally-generated demand. The reason is that resources - machinery and workers - cannot switch instantaneously and without cost from one activity to another, producing goods for expot rather than for domestic use, for example. If a country is experiencing unemployment in industries which are export-oriented, stimulating demand at home may lead to considerable excess demand in some industries, but have little immediate effect on the unemployment in the export industry. That unemployment could be eliminated quickly without excess demand pressures if the demand stimulus came from abroad.

It is not clear, however, that the countries which are supposed to be waiting for the locomotives to pull them out of recession are suffering from unemployment concentrated in their export industries. Futhermore, the consequences of demand expansion for the surplus countries themselves should be con-

¿3:See Wood and Mudd, "The Recent U.S. Trade Deficit," p. 2. 
sidered. It is reasonable to assume that resources in surplus countries do not move any more freely than they do in the deficit countries. As in the deficit countries, these surplus countries do not seem to have spare capacity concentrated in any particular industries. ${ }^{24}$ What will happen when the surplus countries expand demand? They will experience excess demand in the sectors which produce goods for domestic use, and these pressures will be only partly ameliorated by increased imports. Hence, while stickiness of resource movement can be a valid reason for asking the locomotive economies to expand, it can also be a reason for the locomotive economies choosing not to expand! ${ }^{25}$

Summarizing this discussion, one reason for desiring expansion to come from abroad is no longer justifiable given the move to flexible exchange rates. Another, as well as resting on a questionable assumption about the distribution of spare capacity, also provides a reason why the locomotives may very reasonably be unwilling to "get up steam".

\section{Would the Locomotives Pullp}

What will happen to exports and output in the non-locomotive economies of the OECD if the locomotives expand their demand?26 Consider the example of a 1 percent rise in GNP in Germany, an appropriate degree of stimulus in the view of the OECD Secretariat. ${ }^{27}$ On the basis of past experience, this will lead to an increase of about 2 percent (or DM5 billion at 1977 prices) in German imports. Who will benefit from this growth?

The origin of German imports does not vary greatly from year to year. In terms of Germany's immediate European neighbors, one sees that Germany purchases almost 4 percent of its total imports from the United Kingdom, 12 percent from France, and just over 9 percent from Italy. Assuming that these shares

\footnotetext{
24Several countries appear to have excess capacity in the production of certain types of steel, but this excess capacity cannot be utilized without excess capacity at higher stages of production.

2 Slow factor mobility may have prompted some countries to intervene in foreign exchange markets to moderate the appreciation of their currencies. This will retard the rate at which their export industries experience diminished demand and, in turn, allow resources to leave gradually the industries.

${ }^{26} \mathrm{~A}$ more extensive discussion of this point is found in, "Why Prosperity Won't Travel," Citibank Monthly Economic Letter (March 1977), pp. 1-4.

27obeft Mauthner, "OECD Nations in Disarray Over Eco" nomic Growth," Financial Times, May 31, 1978, p. 1 .
}

do not change, this means that of the DM5 billion increase in Germany's imports, the United Kingdom would receive DM0.2 billion, France DM0.6 billion, and Italy DM0.5 billion. Converting these amounts by the exchange rates prevaling at the end of 1977 , these are increases in GNP of 0.05 percent for the United Kingdom, 0.07 percent for France, and 0.15 percent for Italy. These are not tremendously large stimuli.

These OECD countries would benefit even less if Japan expanded demand. Japan is very poor in natural resources; some 80 percent of its imports are primary products. Very little of a Japanese expansion would spill over to the other OECD countries. (Of the OECD economies, the United States would probably feel the greatest impact of a Japanese expansion, and that would not be large; Japan spends only a little over 1.5 percent of its GNP on U.S. goods.)

\section{If They Don' Pull, Are They Causing Unemployment?}

Urging the locomotive countries to expand demand may be based on the idea that they are now "exporting their unemployment," as foreigners buy goods and create employment in the locomotive economies rather than in the weaker countries. If that belief underlies the locomotive approach, then essentially it is being asserted that these surplus countries have resorted to what Joan Robinson called "beggar-my" neighbor remedies for unemployment." 28 That accusation was made against some countries in the early 1930s. But is it a correct diagnosis of the present situation?

This question can be addressed by considering the methods of "exporting unemployment" which were used in the 1930s. Sometimes tariffs on imported goods were raised with the aim of shifting demand to substitute goods produced domestically. Another method intended to produce a rise in domestic employment at the expense of foreign employment was devaluation, a reduction in the foreign currency price at which a particular government would maintain its currency. A currency devaluation large enough to make domestic goods significantly cheaper than their competitors on world markets would, it was believed, divert both foreign and domestic de-

\footnotetext{
28Joan Robinson, "Beggar-My-Neighbor Remedies for Unemployment," Readings in the Theory of International Trade, ed. The American Economic Association (Philadelphia: The Blakiston Company, 1950), pp. 393-407.
} 
mand to home produced goods and thus increase domestic employment. ${ }^{29}$

The body of analysis which justified these remedies for unemployment has been criticized as fundamentally incomplete, in that it neglects the monetary consequences of the measures discussed and regards the exchange rate as a policy tool independent of monetary policy ${ }^{30}$ It is not necessary, however, even to consider that criticism when rejecting the claim that today the surplus countries are engaged in "beggar-my-neighbor" tactics.

That claim can be rejected very straightforwardly by observing that the surplus countries have not resorted to any means to increase their exports further. Neither Germany nor Japan has increased tariffs and their currencies certainly have not depreciated. ${ }^{31}$

Rather than being the result of "beggar-myneighbor" policies, the surpluses on current account reflect the fact that these economies - government and private sectors combined - are net savers out of income. That is, the financial deficit of the government is smaller than the financial surplus of the private sector. Were the surplus countries unable to invest abroad, their interest rates would be driven down and all their savings would be invested domestically. But other countries are willing to borrow these funds and pay rates of interest higher than could be earned on them in the surplus countries. Hence, it is desired by both lenders and borrowers that these funds flow from one group of countries to another, and to effect that transfer of funds the lending countries must run current account surpluses and the borrowing countries current account deficits. ${ }^{32}$

The deficit countries have certainly not been harmed by being able to borrow abroad. Consider the plight of Italy and the United Kingdom, not to mention the less developed countries (LDCs), had these surpluses not been available for borrowing.

29 lbid, p. 396.

${ }^{30}$ Examples of such criticism are Harry G, Johnson, "The Monetary Approach to Balance-of-Payments Theory," pp. 147-67, and Michael Mussa, "Tariffs and the Balance of Payments: A Monetary Approach," pp. 187-221, both in The Monetary Approach to the Balance of Payments, eds. Jacob A. Frenkel and Harry G. Johnson (London: George Allen \& Unwin Ltd, 1976).

31German and Japanese intervention in exchange markets to slow the appreciation of their currencies may have impeded a fall in their exports.

325ee Wood and Mudd, "The Recent U.S. Trade Deficit," pp. 2-3.
These countries would have had to make dramatic cuts in expenditures and employment or else experience reductions in their exchange rates which would have produced enormous, and in the case of the LDCs perhaps insupportable, declines in living standards. The surplus countries have allowed others to be more expansionary than they could have been without the surpluses. They have not forced unemployment on the rest of the world. ${ }^{23}$

\section{What About Inftation?}

Direct Effects of Expansion - If the OECD countries desire to successfully expand output, either by the locomotive or convoy approach, empirical evidence suggests that effective actions must include expansionary monetary policy. ${ }^{3:}$ Empirical evidence also suggests that the rate of monetary expansion determines, after some lag, the rate of increase of the general price level. ${ }^{35}$ Therefore, attempts to achieve faster rates of output growth, even if they have some success in the short run, will lead to faster rates of inflation in the long run. Thus, expansionary policies appear inconsistent with the currently widely accepted objective of reducing inflation rates.

Indirect Effects of Expansion - The convoy approach, rather than being beneficial, would actually produce additional inflationary dangers. A concerted expansion among OECD countries would trigger a boom in worldwide commodity prices, as demand for these primary products increased in the wake of out. put growth in the industrial countries. This occurred in 1972-73. As growth rates picked up in most of

33The above argument is simplified in that it does not stress the simultaneous detemination of exchange rates and the pattern of intemational borrowing and lending. It should not be taken as implying that some countries have exogen ously given trade surpluses which they have to match by lending abroad, but rather as saying that the pattern of trade surpluses and deficits which has emerged at current exchange rates allows funds to flow internationally as both lenders and borrowers desire.

34 Using data for eight industrial countries, Michael W. Keran shows in "Monetary and Fiscal Influences on Economic Activity: The Foreign Experience," this Retiew (Febrtary 1970), pp. 16-28, that if short-run expansionary policies are to be successful, monetary expansion would be more likely to obtain the desired results than fiscal stimulus. Fturthernore, the latest version of the MIT-Penn model of the U.S. economy shows that unless a fiscal stimulus is supported by monetary expansion, its effect on income is short-lived.

${ }^{35} \mathrm{~A}$ portion of the empirical work relying on the expenience of various countries suggesting that monetary expansion leads to inflation has been collected by Karl Brimner and Allar H. Meltzer, eds., The Problem of Inflation, CarnegieRachester Conference Series on Public Policy, Vol. 8 (Amsterdam: North-Holland Publishing Company, 1978), and David Meiselman, ed., Varieties of Monetary Experience (Chicago; The University of Chicago Press, 1970). 


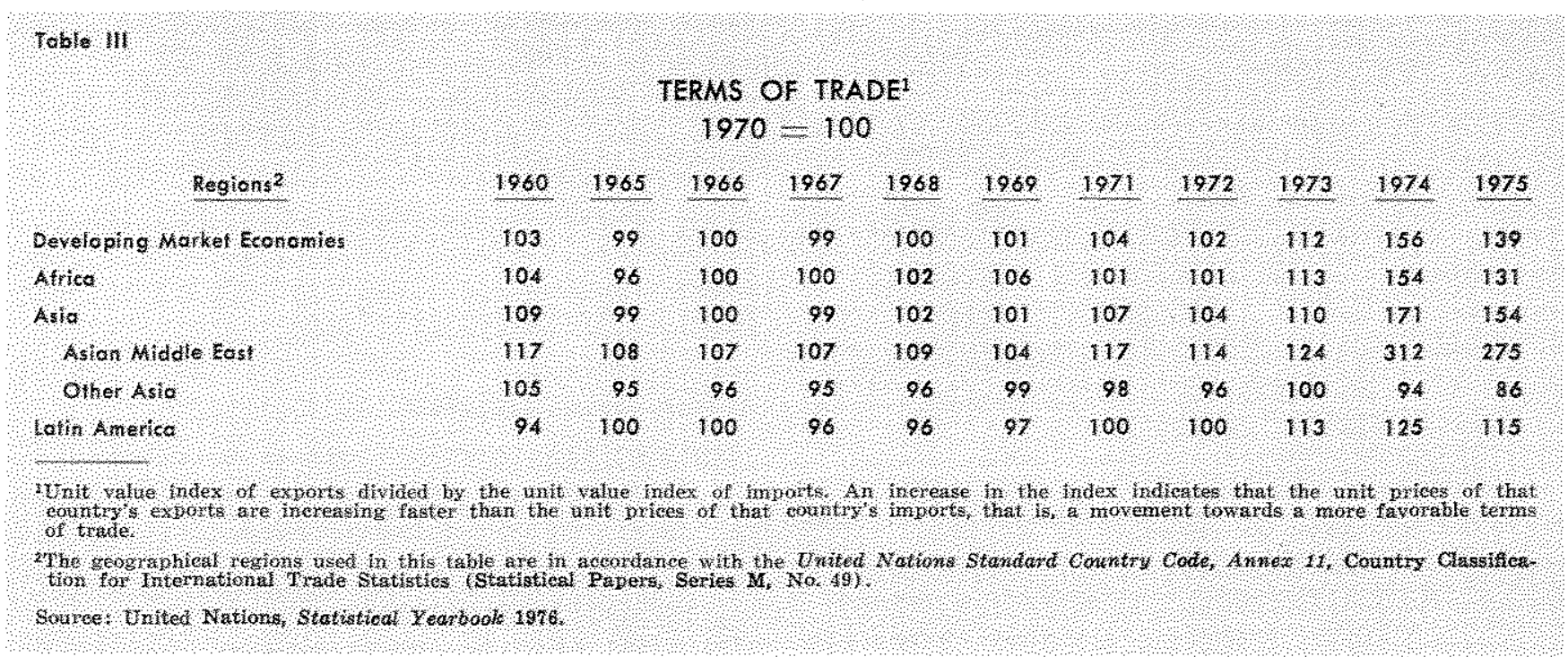

the industrial world, the terms of trade moved shamply in favor of the primary producers (Table III).$^{36}$ Such a change in relative prices can be the result of primary producer prices rising, while $O E C D$ prices remain unchanged; primary product prices remaining constant, while OECD prices fall; or primary producer prices rising faster than $\mathrm{OECD}$ prices. In 1972-73, the latter situation occurred. Since prices rise more easily than they decline, this would be the most probable pattern in the future. Such a rise in prices is not compatible with the objective of restraining price increases.

In addition, as a consequence of the rise in prices, there would be a fall in the purchasing power of the money held by residents of the OECD countries. Expenditures would be squeezed and lead to a reduction in demand in the $O E C D$, thus reversing the initial expansion. The convoy approach would, therefore, increase fiuctuations in employment and output.

Further inflationary pressures are another possible consequence of the convoy approach. As prices of primary products rise relative to the prices of goods

\footnotetext{
36The terms of trade are the prices of the goods a country sells on world markets relative to the prices of the goods it buys. A worsening in the terms of trade is a fall in the price of its exports relative to that of its imports. A series of the terms of trade for the United Kingdom, a particularly open industrial economy, has been published in the National Institute Economio Review (in the Statistical Appendix) for a strbstantial number of years. That series shows that every worldwide expansion has worsened the United Kingdom's terms of trade; $1972-74$ is far from unique. It should be noted that the terms-of-trade movement (for all the oil importing countries) in 1974 was substantially due to the rise in oil prices at the end of 1973 and was not all directly induced by increased economic activity in the West. The terms-of-trade movement in 1973 , however, was clearly demand-induced.
}

produced by the OECD countries, OECD residents would find themselves becoming worse off. They would try to compensate for this by raising the prices of the goods they sell, but at higher prices, less of their product would be demanded. This would be a second force producing an increase in unemployment. OECD govermments would feel pressure to resist the higher unemployment, which could be offset by monetary expansion. Increasing the money stock would generate inflation. In summary, there is a great danger that the convoy approach would both amplify fluctuations in employment and prompt further inflationary pressures.

\section{SUMMATY AND CONCUUSTONS}

The international economy in the 1970 s has been characterized by a greater similarity in rates of growth of output among the major industrialized countries and wider disparities in inflation rates than were experienced in the 1960s. Accompanying these developments have been sharp fluctuations in exchange rates and large differences in the current account balances among nations. Some analysts conterd that these factors will eventually lead to a disruption of international trade and to losses in economic well being throughout the world. Recent proposals to deal with the intemational economic situation have recom mended that the countries of the OECD area coordinate their economic policies and either have an expansion pulled by the strong locomotive economies or all expand together, moving along in a convoy.

In fact, evidence indicates that spare capacity is not as large as many of the proponents of these policies 
seem to believe. Therefore, expansionary policies, either as locomotives or convoys, do not appear to be appropriate in current circumstances.

Proposals calling for an expansion pulled by the locomotive economies appear to be misconceived for other reasons as well. Given the current regime of floating exchange rates, there is no advantage to be gained by waiting for expansion to be led by the locomotives. Furthermore, an acceleration of economic growth in Germany and Japan would provide little additional stimulus to the economies of their OECD trading partners. By not undertaking expan- sionary policies, the proposed locomotive countries can be viewed as supporting the weaker countries, rather than contributing to unemployment in the nonlocomotives as alleged by some analysts.

Finally, and most important, economic expansion, either powered by the locomotive economies or coordinated among the countries in the form of a convoy, could not be achieved without worsening inflation. Thus, rather than improving the intemational economic situation, policies for coordinated international economic expansion would aggravate the problems they were intended to correct.

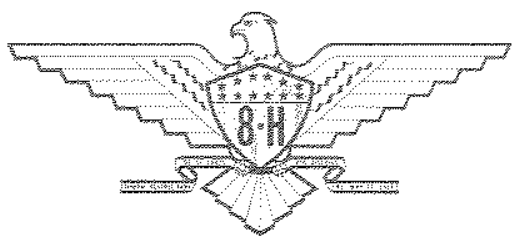

